\title{
The Openseminary Methodology: Practical Theology as Personal, Local and Transformative
}

\author{
Brian Macallan
}

check for

updates

Citation: Macallan, Brian. 2021. The Openseminary Methodology:

Practical Theology as Personal, Local and Transformative. Religions 12: 652 https://doi.org/10.3390/rel12080652

Academic Editor: Sheryl

A. Kujawa-Holbrook

Received: 22 June 2021

Accepted: 14 August 2021

Published: 17 August 202

Publisher's Note: MDPI stays neutral with regard to jurisdictional claims in published maps and institutional affiliations.

Copyright: (C) 2021 by the author. Licensee MDPI, Basel, Switzerland. This article is an open access article distributed under the terms and conditions of the Creative Commons Attribution (CC BY) license (https:// creativecommons.org/licenses/by/ $4.0 /)$
Faculty of Theology, Stirling Theological College, University of Divinity, Melbourne 3170, Australia; bmacallan@stirling.edu.au

\begin{abstract}
Theological education continues to be subject to rapid social and technological change, which is further exacerbated by the recent global pandemic. Practical theology as a discipline continues to grow, being well placed methodologically to engage with diverse contexts and these global realities. The task for theological education is whether it can meet these challenges and be part of the transformation required. Openseminary as a methodology and program was developed in the early 2000s by Wynand De Kock to enable students to both learn practical theology as a methodology, as well as reflect theologically in their own context. Over the last two decades, it has run in South Africa, at Tabor College in Australia, as well as Palmer Seminary in the United States. In what follows, the methodology and program are explored in terms of their genesis, history, and current articulation. It is argued that it is a practical theological methodology well suited to the personal, local, and transformative goals of theological education today.
\end{abstract}

Keywords: Openseminary; practical theology; personal pedagogy; local; transformative

\section{Introduction}

Theological education, and education in general, has endured significant challenges globally due to the COVID-19 pandemic. For both students and teachers, the shift to online learning has created significant stress, generating questions around the nature of pedagogy and the value of theological education. In certain contexts, there has even been a renewed interest in taking up theological studies (Myklebust 2020).

Discussions around post-pandemic pedagogy are hopeful that the resourcefulness drawn on during this crisis might serve to "widen the relevance of education in society" which might encourage "the global community of educators to innovate and share expertise to realize this urgent mission" (McCarty 2020).

The pandemic has at the same time renewed reflections around resilience and how we cope with rapid societal change, raising questions for student's personal and professional careers (Van Dijk-Groeneboer 2020). The pandemic itself has disproportionately affected minority groups, with the worldwide vaccine rollout favouring richer countries. How do we reflect theologically amid injustice and rapid pedagogical change?

Practical theology as a discipline is well placed to serve students and practitioners in this emerging new context. However, as Cross et al. (2021) have reminded us, while "claiming that practical theology is well-poised to respond to questions raised by the pandemic" we should be cognizant of "how might we also recognize that practical theology-with its practices of speech, silence, doing, and meaning-making-is enmeshed in these oppressive systems".

They argue that practical theology in the current context ought to avoid constructing theology that claims to be timeless, and one that claims applicability to a multitude of contexts. ${ }^{1}$ This last sentence in many ways defines the very nature of practical theology, one that is contextual, local, and that seeks to avoid forms of applied theology. ${ }^{2}$ Practical theology is less about the content than it is about methodology. This is not a methodology 
that removes students from their concrete life challenges, but rather moves them towards those realities. In re-imaging theology for a new generation, therefore, practical theology should continue to attempt to embed itself in awards and curriculum that leads students back to their context, teaching them a theological method that responds to the realities in their own life situation. As an article in this current special issue highlights, the DMin can play an important role in this, with its emphasis on practice (Blythe 2021). Although linking the DMin to practical theology can certainly be justified, awards specifically related to practical theology as a discipline are increasing too, although being still rather recent (Bennett and Graham 2008).

This paper seeks to describe a specific methodology called Openseminary that has been in existence for over two decades. It argues that it is a practical theological methodology that is one of many approaches that have, and will continue to have, an important role in theological education. As will be seen, it is different from traditional forms of classical theological education, but with the same goal of equipping students in their vocational context. As a methodology, embedded in an accredited award, it seeks to place contextual and individual stories as central in its deliberations. In what follows I will articulate the history and development of what is called Openseminary, while also describing its core features as found in the Master of Practical Theology (MPT) at Palmer Seminary, Eastern University. I will argue that it is a practical theology that is personal, local, and transformative, and one that can contribute to the unfolding of the future of theological education in a post-pandemic world.

Openseminary was developed by Wynand De Kock in the early 2000s in response to a theological landscape in South Africa that was struggling to find its place in a postapartheid context. ${ }^{3}$ De Kock's development of Openseminary as a methodology needs to be seen against the backdrop of his own life, which he explored in his book Out of my Mind: following the trajectory of God's regenerative story (De Kock 2014).

Kaunda's (2017) recent article exploring a decolonial critique of 'subaltern whiteness' in South Africa has referred to this text as the most interesting book on regenerative theology in post-apartheid South Africa. With reference to de Kock, Kaunda (2017, p. 6) notes that:

He uses narrative of his experiences growing up and living as a privileged Afrikaner under apartheid. He argues that he was indoctrinated to believe that God was sovereign who determined destinies of individuals and nations and that the same God inspired Afrikaner leaders to design the apartheid system to protect cultural purity and racial integrity of Afrikaner people. When he went to do theology, he begun to question the theology that informed him. He believes regeneration begins when an individual begins to ask life- affirming reasonable questions. The Afrikaner's 'inability to ask questions under apartheid was a clear sign that we were in the grip of unreasonable certainty. ${ }^{4}$

Kaunda notes that this led De Kock to explore a new paradigm for doing theology, a praxis of self-generation, and not simply an academic exercise required by the university. The analysis of Cronshaw and Menzies (2014, p. 18) on Openseminary, within an Australian ministry context, focuses on the importance of "questions", its generative nature, and its focus on action.

The aim of Openseminary is to help practitioners cultivate a theological approach to study and ministry that engages questions from their ministry context. Assignments typically identify a live pastoral concern, reflect on this concern while drawing on traditional theological disciplines (biblical studies, systematic and historical theology), identify gaps in knowledge, work towards a generative theological response, and indicate where that might lead in purposeful action.

Kaunda and Cronshaw's engagement with De Kock illustrates the value of exploring Openseminary as a methodology for personal and social transformation. Crucially, I believe, it is important to locate the genesis of the methodology within the life of De Kock 
himself. In this sense, it can be seen as a pedagogy that is personal, emerging out of a life that is lived.

\section{Personal Story as Pedagogy}

De Kock was born during the height of apartheid in the 1960s. In his book, which Kaunda has referred to, he describes growing up in a strongly Afrikaner context in South Africa (De Kock 2014, pp. 5-9). His childhood was shaped by Afrikaner mythology, rooted in its biblical justification. His personal transformation is traced from the electrifying moment of hearing Desmund Tutu speak at his all-white university. It was not so much what Tutu said, but rather "his courage to stand up against the powers that dehumanized him" that moved De Kock (2014, p. xvii).

Along with the encounter with Tutu at university, De Kock describes an encounter with a young black child suffering from foetal alcohol syndrome. He describes his inability to show pastoral care for this child due to his racist upbringing. De Kock began to realise that the theological outlook that had been bequeathed to him was insufficient to make sense of the South African context he found himself in. This led to the importance of questioning and the concept of sacred questions in his rediscovery of faith and God. The centrality of questions would form the cornerstone of the Openseminary methodology he would eventually develop, and which we will discuss shortly. ${ }^{5}$

It would be embedded not only within the methodology itself but within the assessment order and structure. De Kock's (p. 96) encounter with James (the child suffering from foetal alcohol syndrome) took place at Emory University hospital as part of his studies at Chandler School of Theology where he studied Clinical Pastoral Education (CPE). His studies led him into the basement library of Pitts Theological library. If his context had generated questions, his time in the basement library at Pitts would allow those questions to be engaged with sociologically and theologically. He was exposed to political and social literature banned in South Africa, while also delving deep into the theological work of Paul Tillich. It is not difficult to see in the description I've offered a journey from questions driven by ones' context, then being taken up into theoretical reflection. It represents a good practical theological methodology, which again would form a key aspect of Openseminary to come. In time, De Kock would return to South Africa to confront the apartheid system, completing the pastoral cycle ${ }^{6}$ and embracing action. ${ }^{7}$

For de Kock, this ultimately would lead him into pastoring a church in a predominately "grey area" ${ }^{\prime}$, while at the same time being asked to direct a ministry to street children in Cape Town (p. 98). In the early 1990s, in the enormous turmoil running up to the first democratic elections in South Africa in 1994, De Kock would become the principal of a local theological college in a neighbourhood known for its significant political distress. ${ }^{9}$

In the post-apartheid era, the need for a theological education that enabled ministers to take seriously their context, and how to engage with that context, was critical. It is perhaps no surprise that the initial success of Openseminary within a South African context was its ability to allow questions to be central to theological reflection, emphasizing the local and contextual features of that process. Theory, in whatever form, is secondary. Theological reflection then finds its way into action on the ground, and in a specific context. This process is then repeated, for theology is, as De Kock would affirm, always "in process".

De Kock, and Kaunda's engagement with de Kock, emphasizes the regenerative nature of de Kock's journey and the theological outlook that emerged from that journey. The Openseminary methodology that was developed seeks to affirm and foster generative theologies:

Theology that is generative always takes place in the midst of God's redemptive actions in the world. Theology therefore enables us to discern where we are most needed in the mission of God and where the world most needs God's intervention. The place God calls us is the place where faith seeks meaning and meaning seeks faith. So, when we engage the arts, commerce and sciences in our context we can expect to encounter the questions that God's activity in this world 
is stirring up. Generative Theology is therefore always "in process"; it is never finalized (p. 146).

De Kock's story, illustrating a journey from racism under apartheid to a regenerative life, illustrates key aspects of what I will call a personal pedagogy. It demonstrates in a life, how questions emerge from one's own personal and local context, can be engaged with theoretically, and can lead to changing one's view on God, and God's engagement in the world. It is my assessment that this personal pedagogical journey of De Kock ultimately formed the basis for his eventual development of the Openseminary program.

Openseminary as a methodology would, in time, find itself expressed through the Master of Theology at the University of Pretoria, the Master of Vocational Practice at Tabor College (now Eastern College Australia) and currently as the Master of Practical Theology at Palmer Seminary, Eastern University. Over 200 students have graduated from the program across three different continents.

\section{The Openseminary Methodology}

The Openseminary methodology can be described as a practical theological methodology that provides students with a methodology to be able to reflect on their unique context. It embraces the pastoral cycle in its design by helping students to attend, assert, and act in their personal and local context. ${ }^{10}$ The experience is designed to be transformative for the student and their context. In what follows, I will briefly highlight core features of the methodology as it refers to length, modules, assessment, and structure.

\subsection{Length and Focus}

The program is run over three years covering six areas of church practice. The areas covered are: (1) Theologia: Doing Theology in Context, (2) Paideia: Spiritual Formation, (3) Diakonia: Service to Community, (4) Koinonia: Leadership and Community, (5) Leirourgia: Worship, and (6) Kerygma: Proclamation. Hence, these six areas can best be understood in contrast to traditional theological disciplines such as biblical studies, systematic theology, church history, amongst others, which often frame the theological studies curriculum. These traditional disciplines are, however, explored uniquely through these various "lenses" of church practice. ${ }^{11}$

The emphasis on questions and practice is further embedded in the nature of the assessment tasks.

\subsection{Assessment}

Each student conducts a personal inquiry process designed to help them articulate their emerging question for a specific practice. ${ }^{12}$ This is done in concert with the cohort social inquiry process. ${ }^{13}$

Both are designed to help students uncover the unique challenges and questions emerging from their personal and professional contexts. In this sense, it is a common practical theological move, one that seeks to ground theological reflection in the local and contextual nature of reality. ${ }^{14}$ Various theological disciplines are then engaged with in relation to that context. It does not assume a body of knowledge that can be simply applied. This is, rather, consistent with the earlier view that practical theology post-pandemic should continue its focus on theological reflection that is not timeless.

While students are engaged in articulating their emerging questions, through a process of personal and social inquiry related to their unique context, they explore the various insights (traditional answers) from various theological disciplines over a 14-week process. Midway through their 21-week journey, they come together for a three-day integrative seminar (in person or online) where they are exposed to practitioners and academics exploring key aspects of that particular church practice. ${ }^{15}$ 
An example of this was having Shane Claiborne take several sessions in the intensive, exploring poverty and justice as part of the Service in Community module. De Kock refers to these kinds of individuals as "thoughtful practitioners".

Alongside the assessments that explore personal and social realities, students are required to complete two assessments examining whether they have mastered the theory aspect of each unit. These two assessments are a book review and an open book exam. The final seven weeks of each module involve the student completing an operational theology paper. This seeks to integrate all aspects of the module and methodology. Students describe their journey to their emerging question that has come from their context and how some of the traditional answers they have explored speak to that question. However, in critiquing those traditional answers, they explore their unique response to the question and propose specific actions to address that question. Students are required to experiment with these actions and integrate their reflections in the final paper. ${ }^{16}$

In this way, the overall move in the module, and the assessment structure, is an affirmation of the practice-theory-practice process. It resists applied theology while also insisting on the importance of action, and not simply remaining in academic reflection only (Cross et al. 2021).

Students are divided into cohort groups of around five students where peer learning and mentoring take place. A group project, called a social inquiry, takes place within this cohort context. Cronshaw has argued for the importance of cohorts within the Openseminary process as being crucial for fostering ministry skills. ${ }^{17}$

This brief outline of the methodology of Openseminary and its structure illustrates the practical theological grounding of the methodology in the award itself. It further illustrates the centrality of questions, theory as secondary, and the importance of action. It provides students with a methodology, and not simply content. This is consistent with the personal pedagogy that emerged from the short overview of de Kock's life which formed the basis for the methodology itself.

\section{Conclusions}

Practical theology as a discipline is diverse and has grown substantially over the last few decades. There have been attempts to embed practical theological methodology in specific awards and curriculum. This includes the traditional DMin awards, but also professional doctorates. Openseminary embeds a practical theological methodology directly in the structure of the award, both in reversing the influence of traditional theological disciplines, and orientates the award around six areas of practice. It further does this by allowing the assessment type and order to reflect a practice-theory-practice cycle. It prioritizes questions emerging from the student's own unique personal and professional context. It further encourages group work to articulate these concerns. It moves the students towards action as a central feature of theological reflection.

In this sense, the Openseminary methodology offers students not content, but a way of doing theology ${ }^{18}$ It not only enables them the opportunity to transform their context towards a more just and generative space but gives them a methodology they can use for the rest of their lives. It, therefore, has the potential to be one among many options for theological transformation into the future. It is consonant with the aims of this Special Issue in working towards a style of scholarship and leadership "found in the prophets, who both loved and challenged their own traditions. Theological education is about strengthening hearts and challenging minds. At its most basic, it is about creating intentional communities of transformation". Openseminary does this by foregrounding the personal and local, with a goal to transformative action and change. As Kaunda's (2017) engagement with De Kock reminds us "Doing theology became a praxis of self-regeneration first and foremost rather than a mere academic exercise required by the university".

Funding: This research received no external funding.

Institutional Review Board Statement: Not applicable. 
Informed Consent Statement: Not applicable.

Data Availability Statement: Not applicable.

Conflicts of Interest: The author declares no conflict of interest.

\section{Notes}

This is of course consistent with moves in Constructive Theology in general. See (Wyman 2017).

2 Practical theology initially originated within a German context and was largely seen as a form of applied theology. This situation has changed significantly over the last several decades. See (Macallan 2014, p. 66). Practical Theology has moved from a discipline that is focused largely on the end product of Theology. It was previously seen as simply the outworking of an applied theology that tells us what it ought to do. With the changes that have taken place in the last several decades, a noticeable shift in the importance of reflecting on practice as a starting point for theological reflection has been emphasized. Practical Theology has also broadened its concerns from a narrow ecclesial perspective to a more holistic one. The rejection of a timeless theology is also a central feature of open and relational theologies in general, and process theology specifically.

3 Is it possible to describe a methodological family for the open seminary methodology? In some sense yes. It might be located within the praxis/theology in action model described by Graham and Ward (2006).

4 Kaunda's form of regenerative theology argues that "Regenerative theological praxis seeks to interconnect the head and the heart to gain a necessary balance in understanding and interpreting the world and relating to other human beings. It emerges out of indivisibility of mind and heart and is carried out in order to enable an individual or faith community to understand God's mission in the world. Perhaps some Afrikaner theologians must learn how to connect their minds and hearts so that they learn how to listen to the cry of black people-what to listen to and why." (p. 8)

5 De Kock will eventually describe this journey in the following way, "In my pre-seminary days, I believed that to question was to doubt, and to doubt was to be unbelieving-so it was better not to question. The church under apartheid in South Africa seemed to have all the answers. It was "simplicity on this side of complexity;" it was to live my life with training wheels attached to my mind. After my encounter with James, and as I wrestled through the dark night of my soul in Atlanta, and began to experience the pedagogy of the Spirit, the training wheels came off and I could appreciate the place of questioning. As I now stand outside of beliefs that I had inherited as an Afrikaner; I am able to scrutinise, abandon or embrace them. I am able to mind the gaps in my thinking, especially my view of God that shaped by my spiritual formation as an Afrikaner boy. I was ready to ask hard questions about God and the authority of Scripture in my life".

6 The pastoral cycle has a long history in practical theology. It emphasizes the movement from practice to theory and then a return to practice. This cycle is then repeated. See Ballard and Pritchard (2006, p. 82) and Bennett and Graham (2008), locating its genesis in the young christian workers movment.

$7 \quad$ See (De Kock 2014, p. 96). As we commit ourselves to a life that avoids fatedness and encourages God's creation to come to its full potential, we can hear the voice of God breaking through. As we commit ourselves to being troubled by what God is troubled by, then the voice of God becomes perceptible-we embrace his mission and we can begin to live the dangerous adventure of a passionate God.

8 A grey area being defined by the government as one that cannot easily be classified according to racial categories.

9 De Kock (2014, p. 115) describes it thus "The college faced many challenges: it was located in Athlone on the Cape Flats not far from where the notorious Trojan Horse Massacre occurred in 1985. Athlone was filled with tension and college was in the middle of it. From our campus we could see the armoured vehicles of the South African Police and Defence Force storming onto the School Campus across the way, shooting at the brothers, sisters, family and friends of some of our students. We could see young people wandering onto streets, stoning cars, setting up barricades, and finding ways to vent their frustration and rage."

10 See Macallan and Hendriks (2012). "This pastoral cycle is not dissimilar to the theological reflection that James and Evelyn Whitehead propose in their book, Method in Ministry: Theological reflection and Christian ministry, published in 1995. They propose a three-step process similar to the see-judge-act, or the practice-theory-action process for which the pastoral cycle argues. The process that they propose is one of attending, asserting, and then pastoral response (Whitehead and Whitehead 1995, p. 13). One attends to a specific experience or practice that is then brought into dialogue with the Christian tradition and culture where an assertion is made, which in turn leads to a pastoral response. Here, the term "pastoral concern," taken from the Whiteheads, has been used when discussing the first part of the pastoral cycle. The term "pastoral action," similar to the Whitehead's term "pastoral response," is adapted by De Kock. Here, he essentially works with, adapts, and fleshes out the Whiteheads' methodology. He chooses to call the term "pastoral response" or rather "pastoral action." This is done intentionally to show that the pastoral cycle must not end in a theoretical proposal for action but must go beyond that and move to an intervention, or action".

11 In this sense, the approach developed by De Kock is consistent with post-foundationalist turns in theology. See (Macallan 2014, pp. 135-57). "In dealing with both the cultural and the Christian sources, we must take into account an epistemological shift that, in turn, must lead us to a non-foundationalist approach to sources within Practical Theology. This theoretical moment of 
pastoral reflection must result in a theoretical proposal for pastoral action that must then move back to practice in the form of an intervention in the real world".

12 In its current expression at Palmer Seminary, the personal inquiry uses the "Immunity to Change" process for the personal inquiry. The immunity to change process is developed by Kegan and Lahey. See (Keegan and Lahey 2009).

13 Students are placed in cohort groups for the duration of each module. A peer mentoring process takes place in each cohort, as students will be in different stages of their three-year Openseminary journey.

14 As Miller-McLemore comments, "Methodologically practical theology begins with the concrete and local. However, this focus on the particular is not just a methodological choice. It also reminds practical theologians of the more comprehensive aim of their work. Practical theology either has relevance for everyday faith and life or it has little meaning at all". See (Miller-McLemore 2011, p. 7).

15 Cronshaw and Menzies (2014, p. 8) helpfully describe this process, as was done in the Australian context, but still expressed within the United States expression. "Then the whole class meets for a midsemester intensive, usually offsite in a relevant learning context. For example, church leaders have their class in a local church that exemplifies the topic of study-whether worship, spiritual formation, community building, missional service, evangelism, or doing theology in vocational context. The MAVP is less focused on a teacher-learner paradigm and is more about gathering experienced learners together with apprentice learners. Guest Lecturers are not specialist gurus but rather experienced learners assisting others in their growth in ministry".

16 In this sense, Open Seminary shares certain features of DMin projects. Tim Sensing, for example, makes this a core feature of how he understands the DMin and its relationship to qualitative research. See (Sensing 2011).

17 See (Cronshaw and Menzies 2014). The practitioner/students meet as peer groups for their learning and assessment tasks. Students say this is what really helps make the course function at its best, although admittedly a (rarely) poor cohort can make for a poor semester too. Their first assignment each semester is a collaborative social inquiry paper that a cohort group works on together to broadly investigate the topic of interest. Collaborative assessment is a good tool for mutual learning and teamwork, skills that are in themselves integrally important for ministry.

18 De Kock has noted the influence of John De Gruchy in the formation of his own ideas. De Gruchy is noted as being one of the key anti-apartheid theologians in the 1980s in theology. The Doing Theology that De Kock affirms can be seen as being drawn from de Gruchy's understanding of that term. See, Doing Theology in Context was primarily intended as a resource for those studying in seminaries and universities, or through TEE and other such programmes. It was not intended solely as a textbook for students on the path to graduation and ordination. Its purpose was to help ministers, priests, and pastors, and others engaged in ministry or interested in theology, to "do theology" in our context as an ongoing task. Studying theology as part of the process of ministerial formation en route to ordination is important, but it is only the start of a life-long process of doing theology within the context of church and society. See (De Gruchy 2011, pp. 21-31).

\section{References}

Ballard, Paul, and John Pritchard. 2006. Practical Theology in Action: Christian Theology in the Service of Church and Society. London: SPCK. Bennett, Zoe, and Elaine Graham. 2008. The Professional Doctorate in Practical Theology: Developing the Researching Professional in Practical Theology in Higher Education. Journal of Adult Theological Education 5: 33-51. [CrossRef]

Blythe, Stuart. 2021. DMin as Practical Theology. Religions 12: 31. [CrossRef]

Cross, Katie, Clare Louise Radford, and Karen O'Donnell. 2021. Fragments from within the pandemic: Theological experiments in silence, speech, and dislocated time. Practical Theology 14: 144-58. [CrossRef]

Cronshaw, Darren, and Andrew Menzies. 2014. From Place to Place: A Comparative Study of 5 Models of Workplace Formation at 2 Colleges on 1 Campus. In Learning $\mathcal{E}$ Teaching: The Way Ahead. Edited by Les Ball and Jim Harrison. Melbourne: Mosaic, pp. 217-28.

De Gruchy, John. 2011. Revisiting Doing Theology in Context: Re-assessing a Legacy. Journal of Theology for Southern Africa 141: 21.

De Kock, Wynand. 2014. Out of My Mind: Following the Trajectory of God's Regenerative Story. Eugene: Wipf \& Stock.

Graham, Heather Walton, and Francis Ward. 2006. Theological Reflections: Method. London: SCM Press.

Kaunda, Chammah. 2017. Hijacking Subaltern's history (broken bodies, broken voices): Decolonial critique of 'Subaltern whiteness' in South Africa. HTS Teologiese Studies/Theological Studies [Online] 73: 1-9. [CrossRef]

Keegan, Robert, and Lisa Lahey. 2009. Immunity to Change. Harvard: Harvard Business Review.

Macallan, Brian, and Jurgens Hendriks. 2012. A post-foundational Practical Theology? The pastoral cycle and local theology. Dutch Reformed Theological Journal 53: 194-205. [CrossRef]

Macallan, Brian. 2014. Postfoundationlist Reflections in Practical Theology: A Framework for a Discipline in Flux. Eugene: Wipf and Stock.

McCarty, S. 2020. The Journal of Online Education (JOE). Special Issue on Teaching Online during the 2020 Coronavirus Pandemic. New York: New York University.

Miller-McLemore. 2011. The Contributions of Practical Theology. In The Wiley-Blackwell Companion to Practical Theology. Chichester: Blackwell.

Myklebust, Jan Petter. Surge in Interest in Theology due to COVID-19 Pandemic. University World News. Available online: https: / / www.universityworldnews.com/post.php?story=20200915091516361 (accessed on 17 April 2021). 
Sensing, Tim. 2011. Qualitative Research: A Multi-Methods Approach to Projects for Doctor of Ministry Theses. Oregon: Wipf and Stock. Van Dijk-Groeneboer, M. 2020. Religious Education in (Post-)Pandemic Times; Becoming a Resilient Professional in a Teacher Academy. Religions 11: 610. [CrossRef]

Whitehead, James, and Evelyn Whitehead. Method in Ministry: Theological Reflections on Christian Ministry. Lanham: Sheed and Ward. Wyman, Jason, Jr. 2017. Constructing Constructive Theology: An Introductory Sketch. Minneapolis: Fortress. 